University of Nebraska - Lincoln

DigitalCommons@University of Nebraska - Lincoln

Nebraska Beef Cattle Reports

Animal Science Department

2021

Predicting Nitrogen and Phosphorous Flows in Beef Open Lots

Megan N. Homolka

Galen E. Erickson

University of Nebraska - Lincoln, gerickson4@unl.edu

Richard K. Koelsch

Follow this and additional works at: https://digitalcommons.unl.edu/animalscinber

Part of the Large or Food Animal and Equine Medicine Commons, Meat Science Commons, and the Veterinary Preventive Medicine, Epidemiology, and Public Health Commons

Homolka, Megan N.; Erickson, Galen E.; and Koelsch, Richard K., "Predicting Nitrogen and Phosphorous Flows in Beef Open Lots" (2021). Nebraska Beef Cattle Reports. 1105.

https://digitalcommons.unl.edu/animalscinbcr/1105

This Article is brought to you for free and open access by the Animal Science Department at DigitalCommons@University of Nebraska - Lincoln. It has been accepted for inclusion in Nebraska Beef Cattle Reports by an authorized administrator of DigitalCommons@University of Nebraska - Lincoln. 


\section{Predicting Nitrogen and Phosphorous Flows in Beef Open Lots}

\author{
Megan N Homolka \\ Galen E Erickson \\ Richard K Koelsch
}

\begin{abstract}
Summary with Implications
Manure collected from open lot animal housing systems experiences variability due to weather conditions, management of beef cattle and pens, and other factors resulting in substantial changes in manure characteristics. Data from 15 winter and summer periods at the beeffeedlot at Eastern Nebraska Research and Extension Center including 416 independent pen measurements, were summarized for nutrient mass balance, and then used to determine sources of variability impacting nitrogen and phosphorous. Understanding variability is important to regulated manure nutrient planning processes. The results of this review suggest significant challenge associated with planning based upon standard values for estimating manure characteristics. Nutrient planning estimates based upon site and time specific manure analysis is critical for open lot beef systems.
\end{abstract}

\section{Introduction}

Federal and state regulations set environmental standards for beef open lot systems. The U.S. Environmental Protection Agency requires larger open lot systems to be permitted under the National Pollutant Discharge Elimination System (NPDES) process to ensure control of precipitation driven runoff and utilization of manure nutrients in cropping systems. Planning procedures rely upon standard values published by USDA Natural Resource Conservation Service (NRCS) and American Society of Agricultural and Biological Engineers (ASABE) for open lot beef cattle manure quantities and characteristics.

Defining the characteristics of ma-

(C) The Board Regents of the University of Nebraska. All rights reserved.

Table 1. Animal performance data collected from 216 and 200 pens for summer and winter, respectively, for cattle fed in open feedlot ${ }^{1}$.

\begin{tabular}{lccccc}
\hline Item & Summer & Winter & SEM & $P$-value & ASABE $^{3}$ \\
\hline Days on feed & 131 & 171 & 1.9 & $<0.01$ & 153 \\
Initial BW, lb & 800 & 703 & 16.0 & $<0.01$ & 745 \\
Final BW, lb ${ }^{3}$ & 1295 & 1303 & 14.3 & 0.643 & 1220 \\
DMI, lb/d & 25.0 & 22.3 & 0.45 & $<0.01$ & 19.7 \\
ADG, lb/d & 3.77 & 3.49 & 0.035 & 0.05 & 3.13 \\
F:G lb/lb & 0.158 & 0.157 & 0.001 & 0.490 & 0.16 \\
Crude protein diet, \% & 14.7 & 16.1 & 0.26 & $<0.01$ & 13.4 \\
Phosphorus in diet, \% & 0.33 & 0.31 & 0.006 & 0.067 & 0.31 \\
Total Precipitation (in) & 13.9 & 9.0 & 0.35 & $<0.01$ & \\
\hline
\end{tabular}

${ }^{1}$ SUMMER = cattle fed from April to October, WINTER = cattle fed from November to May

${ }^{2}$ Calculated from hot carcass weight, adjusted to $63 \%$ common dress.

${ }^{3}$ ASABE: American Society of Agricultural Engineers Standard D384.2, Manure Production and Characteristics.

nure and runoff from open earthen lots experiences unique challenges compared with confined animals under roof including variables such as:

- Climatic conditions impacts,

- Pen manager's challenge for distinguishing between compacted soil and manure,

- Animal and manure management practice (e.g. frequency of manure collection),

- Diets fed due to ability of ruminant animals to utilize a variety of byproducts, forages and crop residues.

\section{Procedure}

This paper summarizes an existing database collected from cattle finishing trials conducted at Eastern Nebraska Research and Extension Center (ENREC) facility. Over a 15 -year period, 416 unique pen observations were evaluated for the impacts of a broad range of weather conditions, dietary treatments, feedlot management practices and nitrogen and phosphorous conservation practices led by Drs. Galen Erickson and Terry Klopfenstein (Table 1).
Historically, the data has primarily added to knowledge of dietary impact on animal performance. A pooled analysis of manure and nutrient characteristics from the pen data was performed.

Trial methods followed common procedures for estimating animal performance, nutrient intake and excretion, as-removed manure, and runoff quantities. Losses of nitrogen $(\mathrm{N})$ and phosphorus $(\mathrm{P})$ were estimated using a mass balance comparison of nutrient inputs and known outputs with the difference representing losses or unaccounted $\mathrm{P}$ (P remaining in the lot after cleaning).

Standard methods were followed for harvesting manure and determining mass. Representative samples collected for manure and runoff characteristics were frozen at $-4^{\circ} \mathrm{C}$ until analysis. When rainfall occurred, runoff was collected, sampled, and quantified. Standard methods were followed for all manure solids and nutrient analysis following official methods of Association of Official Agricultural Chemists International. The mass data of these trials was assembled in an excel file where analysis was initially completed followed by linear regression SAS to define important correlations. 
Table 2. Nitrogen, phosphorus, and dry matter characteristics associated with 216 pens during the summer and 200 pens during the winter for cattle fed in open feedlot pens.

\begin{tabular}{|c|c|c|c|c|c|}
\hline $\mathrm{N}$ Characteristics & Summer & Winter & SEM & P-value & $\mathrm{ASABE}^{8}$ \\
\hline $\mathrm{N}$ intake, lb/head/d & $0.54 \mathrm{a}$ & 0.50 & 0.006 & $<0.01$ & 0.42 \\
\hline $\mathrm{N}$ retain, $\mathrm{lb} /$ head $/ \mathrm{d}^{2}$ & $0.068 \mathrm{a}$ & 0.066 & & & 0.063 \\
\hline $\mathrm{N}$ excreted, lb/head/ $\mathrm{d}^{3}$ & 0.48 & 0.43 & & & 0.36 \\
\hline $\mathrm{N}$ runoff, lb/head/d ${ }^{4}$ & 0.014 & 0.008 & 0.0009 & $<0.01$ & \\
\hline $\mathrm{N}$ manure, lb/head/d & 0.11 & 0.20 & 0.004 & $<0.01$ & 0.20 \\
\hline $\mathrm{N}$ loss, lb/head/d $\mathrm{d}^{5}$ & 0.35 & 0.22 & 0.006 & $<0.01$ & \\
\hline $\mathrm{N}$ manure, $\%$ & 1.31 & 1.19 & & & 1.8 \\
\hline $\mathrm{N}$ loss, $\%^{6}$ & $73 \%$ & $52 \%$ & & & \\
\hline P Characteristics & Summer & Winter & SEM & P-value & $\mathrm{ASABE}^{8}$ \\
\hline $\mathrm{P}$ intake, $\mathrm{lb} /$ head/d & 0.083 & 0.071 & 0.0022 & $<0.01$ & 0.062 \\
\hline P excreted, lb/head/ $\mathrm{d}^{3}$ & 0.067 & 0.056 & & & 0.049 \\
\hline $\mathrm{P}$ retain, $\mathrm{lb} / \mathrm{head} / \mathrm{d}$ & 0.016 & 0.015 & & & 0.013 \\
\hline P runoff, lb/head/ $\mathrm{d}^{4}$ & 0.0050 & 0.0023 & 0.00040 & $<0.01$ & \\
\hline $\mathrm{P}$ manure, $\mathrm{lb} / \mathrm{head} / \mathrm{d}^{7}$ & 0.039 & 0.067 & 0.0023 & $<0.01$ & 0.082 \\
\hline $\mathrm{P}$ manure, $\%$ & 0.37 & 0.38 & 0.01 & 0.32 & 0.74 \\
\hline Unaccounted & 0.023 & -0.014 & & & \\
\hline DM Characteristics & Summer & Winter & SEM & $\mathrm{P}$-value & $\mathrm{ASABE}^{8}$ \\
\hline As-is, lb/head/d & 20.5 & 28.9 & 1.83 & $<0.01$ & 16.5 \\
\hline DM, lb/head/d & $11.9^{9}$ & $17.6^{9}$ & 1.56 & $<0.01$ & 11.0 \\
\hline OM, lb/head/d & $2.2^{9}$ & $4.1^{9}$ & 0.11 & $<0.01$ & 3.3 \\
\hline Ash, lb/head/d & $9.2^{9}$ & $13.4^{9}$ & 0.66 & $<0.01$ & 7.7 \\
\hline
\end{tabular}

${ }^{1}$ Summer $=$ cattle fed from April to October, Winter $=$ cattle fed from November to May.

${ }^{2}$ Calculated using NRC (1996) net protein and net energy equations.

${ }^{3}$ Calculated as $\mathrm{N}$ or $\mathrm{P}$ intake minus $\mathrm{N}$ or P retention.

${ }^{4}$ Number of retention ponds from which data were collected were $\mathrm{n}=84$ in each feeding period for $\mathrm{N}$ and $\mathrm{n}=72$ for $\mathrm{P}$

${ }^{5}$ Calculated as $\mathrm{N}$ intake minus $\mathrm{N}$ retained minus $\mathrm{N}$ manure minus $\mathrm{N}$ runoff.

${ }^{6}$ Calculated as $\mathrm{N}$ lost divided by $\mathrm{N}$ excretion.

${ }^{7}$ Number of pens from which data were collected were 132 and 124 in the SUMMER and WINTER, respectively.

${ }^{8}$ ASABE: American Society of Agricultural Engineers Standard D384.2, Manure Production and Characteristics.

${ }^{9}$ Typically, ash plus OM should equal DM. However, data base did not include ash and OM for some pen trials. Thus, reported averages for ash and OM did not precisely match the reported averages for DM.

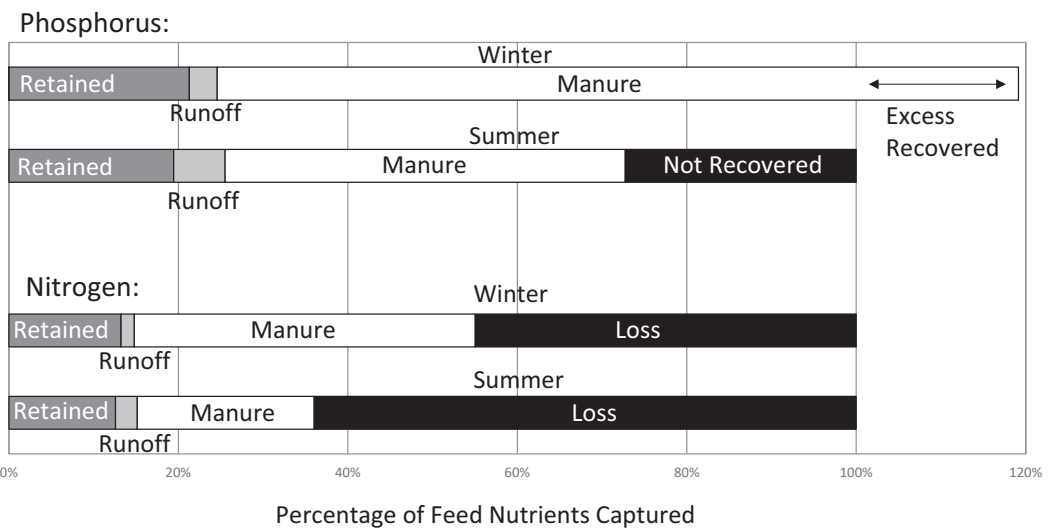

Figure 1. End points for dietary nitrogen and phosphorus consumed by beef for summer and winterfeeding periods.

106 2021 Nebraska Beef Cattle Report

\section{Results}

\section{Nitrogen Balance}

Nitrogen entering a feedlot pen as feed will exit the pen in the marketed animal (retained), runoff holding pond water, as-removed manure, and $\mathrm{N}$ loss occurring predominantly as ammonia volatilization (Table 2; Figure 1). The evaluation of the independent pen measurements at ENREC suggests that $\mathrm{N}$ retained by the marketed animal (approximately $13 \%$ of $\mathrm{N}$ in feed) are consistent between winter and summerfeeding periods. Nitrogen retained in the manure, runoff and lost is significantly different for winter and summer periods. Nitrogen loss ranged from $65 \%$ to $44 \%$ of fed $\mathrm{N}$ for summer and winter, respectively. As a result of changes in loss during these feeding periods, the manure retains 0.11 and $0.20 \mathrm{lb} / \mathrm{head} /$ day for summer and winter periods, respectively, of the 0.54 and $0.50 \mathrm{lb} / \mathrm{head} /$ day of nitrogen intake as feed. Feeding period season (summer vs. winter) is an important factor influencing $\mathrm{N}$ recovered from open lot systems.

Feed nitrogen intake provides some explanation for observed variability of as-removed manure $\mathrm{N}$ and $\mathrm{N}$ loss (Table 3) for manure harvested following a summer feeding period, less explanation for the winter feeding period. The data set suggests that an increase of dietary intake of $1 \mathrm{lb}$ results in approximately a $0.30 \mathrm{lb}$ increase in as-removed manure $\mathrm{N}$ during the summer (no relationship during the winter). This review suggests that an increase of dietary intake of $1 \mathrm{lb}$ is responsible for a $0.61 \mathrm{lb}$ and $0.84 \mathrm{lb}$ increase in $\mathrm{N}$ loss for summer and winter-feeding periods, respectively. A better correlation was observed between $\mathrm{N}$ intake and $\mathrm{N}$ lost for the summer months $[\mathrm{R} 2=0.54(\mathrm{P}<0.01)]$ and for the winterfeeding period $[\mathrm{R} 2=0.37(\mathrm{P}<0.01)]$.

This review of the correlation between organic matter and $\mathrm{N}$ in the manure (Table 3) suggests a strong relationship $\left(R^{2}=0.85\right.$ for summer and 0.70 for winter, $\mathrm{P}<0.01$ for both). Increasing manure's organic matter also appears to reduce $\mathrm{N}$ losses. Management practices that increase manure organic matter will impact planning for as-removed manure $\mathrm{N}$ and may moderately reduce $\mathrm{N}$ emissions. 
Table 3. Summary of the ability of some independent variables $(\mathrm{X})$ such as feed intake $\mathrm{N}$ to predict dependent variables $(\mathrm{Y})$ such as $\mathrm{N}$ in manure for summer and winter-feeding periods (expressed as grams per head per day on feed).

\begin{tabular}{|c|c|c|c|c|c|}
\hline $\mathrm{X}$ & $\mathrm{Y}$ & Season & Equation & Adj. $R^{2}$ & P Value \\
\hline \multicolumn{6}{|c|}{ Feed Intake Factors Potentially Impacting $\mathrm{N}$ in Manure and $\mathrm{N}$ Lost } \\
\hline Nintake & Nmanure & Summer & $\begin{array}{c}\text { Nmanure }=0.29 \\
(+/-0.037) * \text { Nintake }-21 \\
(+/-9.4)\end{array}$ & 0.22 & $<0.01$ \\
\hline Nintake & Nmanure & Winter & NO RELATIONSHIP & N/A & $\mathrm{N} / \mathrm{A}$ \\
\hline Nintake & Nlost & Summer & $\begin{array}{c}\text { Nlost }=0.61(+/-0.038) * \\
\text { Nintake }+5.9(+/-9.6)\end{array}$ & 0.54 & $<0.01$ \\
\hline Nintake & Nlost & Winter & $\begin{array}{c}\text { Nlost }=0.84(+/-0.077) * \\
\text { Nintake }-93(+/-18)\end{array}$ & 0.37 & $<0.01$ \\
\hline \multicolumn{6}{|c|}{ Feed Intake Factors Potentially Impacting P in Manure } \\
\hline Pintake & Pmanure & Summer & $\begin{array}{c}\text { Pmanure }=0.34(+/-0.073) \\
* \text { Pintake }+5.0(+/-2.9)\end{array}$ & 0.13 & $<0.01$ \\
\hline Pintake & Pmanure & Winter & $\begin{array}{l}\text { Pmanure }=0.46(+/-0.12) \\
* \text { Pintake }+11.2(+/-4.0)\end{array}$ & 0.12 & $<0.01$ \\
\hline \multicolumn{6}{|c|}{ Organic Matter in Manure Potential Impact on $\mathrm{N}$ in Manure and $\mathrm{N}$ Lost } \\
\hline OMmanure & Nmanure & Summer & $\begin{array}{c}\mathrm{Nman}=0.045(+/-0.0013) \\
* \mathrm{OMman}+8.0(+/-1.5)\end{array}$ & 0.85 & $<0.01$ \\
\hline OMmanure & Nmanure & Winter & $\begin{array}{c}\mathrm{Nman}=0.033 \\
(+/-0.00152) * \text { OMman }+ \\
29(+/-3.1)\end{array}$ & 0.70 & $<0.01$ \\
\hline OMmanure & Nlost & Summer & $\begin{array}{l}\text { Nlost }=-0.014(+/-0.0046) \\
\star \text { OMman }+170(+/-5.3)\end{array}$ & 0.040 & $<0.01$ \\
\hline OMmanure & Nlost & Winter & $\begin{array}{c}\text { Nlost }=-0.024(+/-0.0042) \\
* \text { OMman }+140(+/-8.4)\end{array}$ & 0.14 & $<0.01$ \\
\hline
\end{tabular}

\section{Phosphorus Balance}

Phosphorus entering a feedlot pen as feed will exit the pen in the marketed animal (retained), runoff holding pond water, or manure (Table 2; Figure 1). Again, the fraction of $\mathrm{P}$ retained by the animal remained relatively constant for summer vs winter periods. The as-removed manure $\mathrm{P}$ was substantially greater in the winter than summer, exceeding the winter estimate of excreted $P$. The manure $P$ for summer and winter represented $47 \%$ and $95 \%$ of fed $P$, respectively. The runoff $\mathrm{P}$ during the summer was double that observed during the winter-feeding period ( 6 vs $3 \%$ of fed P).

These results suggest that a $\mathrm{P}$ balance based upon these four inputs and outputs left some P unaccounted, approximately $10 \mathrm{~g} / \mathrm{head} /$ day in the summer (likely left on the lot surface or mixed in the soil) and $-6 \mathrm{~g} / \mathrm{head} /$ day in the winter. Pen cleaning practice in fall following a summer-feeding period (lot surfaces are drier and soil/ manure interface is more easily maintained) resulted in some excreted P not being removed from the pens. Spring pen ing pre-defined protocols for managing pen surfaces as used at the ENREC feedlot. Total manure, total solids, total organic matter, and total ash were all significantly greater for the winter versus summerfeeding period when expressed on a unit mass per head per day basis. For example, cleaning following winter-feeding period is removing $47 \%$ more ash (most likely soil), $87 \%$ more organic matter, and $56 \%$ more total manure.

These observations of manure solids characteristics variation with winter and summer-feeding period (and similar previous observations for $\mathrm{N}$ and $\mathrm{P}$ ) suggest the need for characterizing and managing manure independently based upon feeding period. Differences at the ENREC feedlot, are due, in part to a summer-feeding period which included higher $\mathrm{N}$ and $\mathrm{P}$ feed intake, shorter feeding period, and larger animals entering the lot. Differences in weather conditions and pen surface conditions during the time the cattle were in the pens are likely important contributors to variability, commonly impacting the amount of soil (ash content in Table 2) contamination that occurs.

\section{Comparison with Standard Values}

As animal performance, feeding program options, and other management practices evolve, standard methods for predicting feedlot manure characteristics and quantities are prone to greater errors. When ASABE assumptions and estimates are compared with field measures in this study, the following observations were made:

- Greater total feed intake, higher average daily gains, and greater finishing weights were observed for the animals finished at the ENREC feedlot, better reflecting industry trends, than the assumed values in the ASABE standard (originally published in 2004).

- ASABE underestimates the dietary N intake and excreted $\mathrm{N}$ observed for the ENREC feedlot. Our observed P dietary intake and excretion was also greater than estimated by ASABE. feeding period variability in the amount of manure harvested was also observed (seasonal variability illustrated in Table 2). Variability in the amount of as-removed manure quantity occurs even when follow-
ASABE substantially underestimate total manure, dry matter, organic matter, and ash for winter feeding periods. For example, total as- 
removed manure averages for both winter, $28.9 \mathrm{lb} / \mathrm{head} /$ day, and summer feeding periods, $20.5 \mathrm{lb} /$ head/ day, were greater than that of ASABE standards at $16.5 \mathrm{lb} /$ head/day. The ENREC data set also suggests a greater level of ash in the manure than anticipated by ASABE.

- As-removed manure $\mathrm{N}$ following winter feeding period for the ENREC feedlot was similar to the ASABE estimate but substantially less following the summer-feeding period. Manure P levels were substantially less than reported by ASABE (more than $50 \%$ less in the summer-feeding period). Reduced summer feeding period manure $\mathrm{P}$ may be due, in part to $\mathrm{P}$ left behind by manure removal in summer followed by its removal the following winter feeding period.

\section{Summary}

Standard values for estimating excreted and as-removed manure have historically been used for many planning and design procedures including development of nutrient management plans (often completed years in advance of manure application). These standard values have little to no validity in earthen open-lot animal housing based upon these observations for ENREC feedlot.

In commercial yards that harvest manure following each feeding period (or possibly more often), separately monitoring and managing manure for unique feeding periods is important. Nutrient planning processes should be based on manure sampling protocols that establish a history of feedlot specific manure characteristics, including separate histories for manure removed following winter and summerfeeding periods. Due to the high degree of variability in manure characteristics for individual years and seasons, individual year adjustments for manure and fertilizer rates are essential and should be based upon a just in time manure sample analysis.

Ammonia volatilization from open lots is substantial. For every 1,000 head finished at the ENREC feedlot, the nitrogen loss is approximately 21,000 and $17,000 \mathrm{~kg}$ of $\mathrm{N}$ for the summer and winter-feeding periods, respectively. This loss is an environmental risks and represents an annual economic loss of roughly $\$ 35,000$ per 1,000 head for the ENREC feedlot. Experience would suggest that by doubling organic matter in the manure, one might expect to retain approximately two-thirds more nitrogen in the manure.

\section{Acknowledgements}

Financial support from Robert and Karla Baltzell Student Innovation Award, University of Nebraska-Lincoln.

Megan N Homolka, Undergraduate student, Animal Science, University of Nebraska-Lincoln

Galen E Erickson, Professor, Animal Science, University of Nebraska-Lincoln

Richard K Koelsch, Professor, Biological Systems Engineering, University of Nebraska-Lincoln 